\title{
Pengaruh Akuntansi Dana Desa dan Partisipasi Masyarakat terhadap Pengelolaan Dana Desa
}

\author{
Yustin Novia Pratiwi*
}

Prodi Akuntansi, Fakultas Ilmu Ekonomi dan Bisnis, Universitas Islam

Bandung, Indonesia.

*yustinnoviapratiwi@gmail.com

\begin{abstract}
Today village funds are one of the topics being discussed hotly, in their implementation of the many deviations of priority development funds carried out because they increase understanding of village funds and increase community participation in village fund management. This research was made with the aim to study the effect of village funds and community participation on village fund management. The test tool in this study is a simple and multiple linear regression analysis using SPSS software. This research uses quantitative methods using surveys. In this study, the technique used in collecting data consisted of 62 questionnaires distributed by 62 people to villages and village communities in the area of West Bandung Regency. The results show that the village financial statements have gone well against the system, community participation has gone well and involves accounting of village funds and community participation in the management of village funds.
\end{abstract}

\section{Keywords: Accounting, Contribution , Management , Village Fund}

Abstrak. Dewasa ini dana desa adalah salah satu topik yang sedang hangat dibicarakan, pada pelaksanaanya seringkali banyak penyimpangan dana maupun prioritas pelaksanaan pembangunan yang terjadi karena kurangnya pemahaman atas akuntansi dana desa dan kurangnya partisipasi masyarkat dalam pengelolaan dana desa. Penelitian ini dibuat dengan tujuan untuk mengetahui pengaruh akuntansi dana desa dan partisipasi masyarakat terhadap pengelolaan dana desa . Alat uji dalam penelitian ini ialah analisis regresi linier sederhana dan berganda dengan menggunakan software SPSS. Penelitian ini menggunakan metode kuantitatif dengan pendekatan survey . Dalam penelitian ini, teknik yang digunakan dalam pengumpulan data berupa kuisioner yang disebarkan sebanyak 62 kepada para aparatur desa dan masyarakat desa di wilayah Kabupaten Bandung Barat . Hasil penelitian menunjukan bahwa pada umumnya akuntansi dana desa sudah berjalan dengan baik disertai dengan sistemnya, partisipasi masyarakat sudah berjalan dengan baik dan terdapat pengaruh akuntansi dana desa dan partisipasi masyarakat terhadap pengelolaan dana desa.

Kata Kunci: Akuntansi, Partisipasi ,Pengelolaan, Dana Desa. 


\section{A. Pendahuluan}

Indonesia pernah berada pada sistem perekonomian sentralistik yaitu pada zaman rezim Soeharto (1967-1998). Kemudian seiring perkembangan waktu indonesia beralih pada sistem desentralisasi. Desentralisasi sendiri menurut Undang-Undang No 32 Tahun 2004 adalah penyerahan wewenang dari pmerintah pusat kepada daerah otonom untuk mengatur dan mengurus urusan pemerintahan dalam sistem Negara Kesatuan Republik Indonesia. Seiring berjalannya waktu perekonomian di indonesia semakin gencar melakukan langkah-langkah perubahan dalam rangka mencapai tingkat kesejahteraan terutama dalam program kabinet kerja Presiden Joko Widodo yang berkaitan dengan representasi unit terkecil tonggak pembangunan Insfrastuktur Indonesia. Salah satu langkahnya adalah dengan dibentuknya Undang-Undang Republik Indonesia Nomor 6 Tahun 2014 Dan Peraturan Mentri Dalam Negri Republik Indonesia Nomor 113 pasal 1 ayat 6 Tahun 2014 yang berkaitan dengan pengelolaan dana desa menyatakan bahwa Pengelolaan Keuangan Desa adalah seluruh kegiatan yang meliputi perencanaan, pelaksanaan, penatausahaan, pelaporan, dan pertanggungjawaban keuangan desa. Peraturan tersebut menjadi angin segar bagi desa-desa di Indonesia sekaligus memberikan bukti ketegasan dan keseriusan pemerintah dalam membangun ekonomi Indonesia serta sebagai sarana perlindungan secara yuridis dan pemberdayaan desa agar menjadi lebih mandiri, sejahtera dan demokratis . Dana desa di kucurkan dengan jumlah yang fantantis disetiap triwulannya dengan tujuan untuk memeratakan kesejahteraan dan kualitas sumber daya manusia di Indonesia. Pengelolaan dana desa diharapkan dapat berjalan secara optimal namun, tak jarang dana desa dikelola dengan sistem tidak baik. Dana desa nampaknya menjadi kesempatan atau lahan bagi para oknum desa untuk melakukan penyimpangan salah satunya dilansir dari Kompas.com. Kabul santoso terkena operasi tangkap tangan KPK yang bahkan merugikan negara sebesar 137.9 juta rupiah. Kemudian, dilansir dari Liputan6.com mentri keuangan Sri mulyani menyebutkan karena adanya transfer tetap dari anggaran pendapatan dan belanja negara. Sekarang banyak muncul desa-desa fiktif yang bahkan tidak ada penduduk didalamnya. Berdasarkan latar belakang tersebut maka peneliti tertarik untuk meneliti lebih lanjut prihal dana desa dengan rumusan masalah sebagai berikut: (1) Bagaimana pengaruh akuntansi dana desa terhadap pengelolaan dana desa? (2) Bagaimana pengaruh partisipasi masyarakat terhadap pengelolaan dana desa?

Rumusan masalah tersebut, ditujukan untuk mengetahui (1) tujuan akuntansi dana desa terhadap pengelolaan dana desa (2)tujuan partisipasi masyarakat terhadap pengelelolaan dana desa.

\section{B. Landasan Teori}

Teori Keagenan Menurut Jansen dan Meckling (1976) dalam Syarifudin (2014:30) dapat di definisikan sebagai suatu hubungan yang terdapat pada sebuah kontrak dimana satu orang atau lebih (Principal) memerintah orang lain (Agent) untuk membuat keputusan yang terbaik bagi Principal. Dalam hal ini aparatur desa menjadi agen danmendapatkan mandat untuk mengelola dana desa bagi masyarakat yang berperan sebagai pricipal atau sasaran adanya dana desa. Dalam mengelola dana desa tentunya sangat dibutuhkan laporan keuangan sebagai bentuk tanggung jawab aparatur desa kepada masyarakat dan pemerintah pusat. Laporan keuangan dibentuk dari proses akuntansi atau pencatan dari setiap kegiatan selama dana desa. Akuntansi dana desa menurut Sujarweni (2015:17) adalah pencatatan dari proses transaksi yang terjadi di desa, dibuktikan dengan nota-nota kemudian dilakukan pencatatan dan pelaporan keuangan sehingga akan menghasilkan informasi dalam bentuk laporan keuangan yang digunkan pihak-pihak yang berhubungan dengan desa. Dalam hal ini pengelolaan bukan hanya dilakukan oleh aparatur desa saja tetapi seharusnya dilakukan oleh masyarakat juga. Partisipasi masyarakat sangat dibutuhkan untuk memastikan bahwa dana desa dilaksanakan sesuai dengan prioritas atau kebutuhan desa dan masyarakatnya serta untuk mengawasi jalannya dana desa . karakteristik laporan keuangan menurut Ratmono dan Solihin (2015:15) sebagai berikut: 
1. Relevan

2. Andal

3. Dapat Dibandingkan

4. Dapat Dipahami

Partisipasi masyarakat diartikan oleh Adi (2007:27) sebagai keikutsertaan masyarakat dalam proses mengidentifikasi masalah dan potensi yang ada di masyarakat, pemilihan dan pengambilan keputusan tentang alternatif solusi untuk menangani masalah, pelaksanaan upaya mengatasi masalah, dan keterlibatan masyarakat dalam proses mengevaluasi perubahan yang terjadi”. prinsip partisipasi sendiri menurut Bastian (2015:119) adalah:

1. Ketepatan waktu

2. Akuntabilitas

3. Inklusif

4. Metodologi yang Tanggap dan Sesuai

5. Keberlanjutan Proses Partisipasi

6. Sumber Daya yang Memadai

Dengan demikian , Teori agensi memberikan gambaran bahwa seharunya aparatur desa (agent) dan masyarakat sebagai (principal) saling bekerja sama dalam pengelolaan dana desa. Aparatur desa memberikan yang terbaik bagi masyarakat lewat pemahamannya terhadap akuntansi dana desa dan masyarakat membantu mewujudkan pengoptimalaan dana desa lewat partisipasinya. Agar dana desa dapat dijalan kan sesuai dengan prosedur seharusnya.

\section{Hasil Penelitian dan Pembahasan}

Berikut ini pengaruh antara akuntansi dana desa terhadap pengelolaan dana desa yang diuji menggunakan analisis regresi sederhana

Tabel 1. Uji pengaruh antara akuntansi dana desa terhadap pengelolaan dana desa

\begin{tabular}{|l|l|l|l|l|}
\hline Variabel & $\begin{array}{c}\text { Koefesien } \\
\text { regresi }\end{array}$ & $\begin{array}{c}\mathrm{T} \\
\text { hitung }\end{array}$ & Sig \\
\cline { 2 - 5 } & Konstanta & 17.318 & 4.526 & 0.000 \\
\hline $\begin{array}{l}\text { ADD- } \\
\text { PDD }\end{array}$ & 0.563 & 4.472 & 0.000 \\
\cline { 2 - 5 } & $\mathrm{R}$ & 0.563 & & \\
\hline $\mathrm{r}^{2}$ & 0.317 & & \\
\hline
\end{tabular}

Hasil dari pengolahan data diatas dapat diketahui besarnya koefisien korelasi adalah 0.563. dan Nilai r2. atau koefisien determinasi Sebesar 0.317 berarti sebesar pengelolaan dana desa dipengaruhi sebesar 31,7\% oleh akuntansi dana desa dengan signifikansi sebesar 0.000 . Maka dapat disimpulkan bahwa terdapat pengaruh akuntansi dana desa terhadap pengelolaan dana desa. Hasil tersebut juga didapatkan dari beberapa faktor yang mempengaruhi salah satunya Laporan keuangan desa yang lahir dari pemahaman aparatur desa terkait Akuntansi dana desa. Pemahaman aparatur desa dapat menghasilkan laporan keuangan yang bukan hanya sesuai standar saja tapi informasi yang dihasilkan nya juga akan mudah dipahami. Dalam hal ini aparatur desa dituntut untuk patuh dan paham . karena sebagai agent aparatur desa juga berkewajibkan menghasilkan output atau keputusan yang terbaik bagi principal (masyarakat). Jalannya akuntansi dana desa juga dipengaruhi oleh tingkat pengawasan . Semakin baiknnya pengawasan jalannya proses akuntansi dana desa , maka akan baik juga pengelolaan dana desa yg dihasilkan. Pengawasan dana desa dilakukan oleh pihak internal(Badan Permusyawaratan Desa) dan eksternal (Inspektorat Kabupaten dan Badann Pengawas Keuangan). Berdasarkan uraian diatas maka hipotesis dari penelitian ini sejalan atau diterima sesuai dengan penelitian 
yang dilakukan oleh Sri fadilah dkk (2019:1) yang berjudul pengaruh penerapan sistem pengendalian intern pemerintahan (SPIP) dan kompetensi sumber daya manusia terhadap laporan keuangan pemerintah daerah (survey pada pemerintah daerah bandung raya) bahwa laporan keuangan pemerintah di bandung raya pada umunya sudah berkualitas . hal tersebut berarti bahwa pemahaman akuntansi dana desa juga sudah baik. Selain itu, pada saat wawancara salah satu aparatur desa Dadi mengungkapkan bahwa:

"Pelaporan dana desa diusahkan selalu tepat waktu, namun terkadang informasi prihal pembangunan sulit didapat, ada kendala seperti hilang bon dan macam-macam karena kan ketka pembangunan masyarakat yang membuat tim untuk itu"

Hal tersebut bermakna bahwa bukan hanya aparatur desa saja yang sangat membutuhkan pelatihan dana desa tetapi juga masyarakat karena masyarakat juga sudah mulai terlibat dalam pelaksanaan dana desa dan menentukan seberapa besar ketepatan waktu dalam penyampaian laporan keuangan desa.

Berikut ini pengaruh antara partisipasi masyarakat terhadap pengelolaan dana desa:

Tabel 2. Uji pengaruh antara partisipasi masyarakat terhadap pengelolaan dana desa

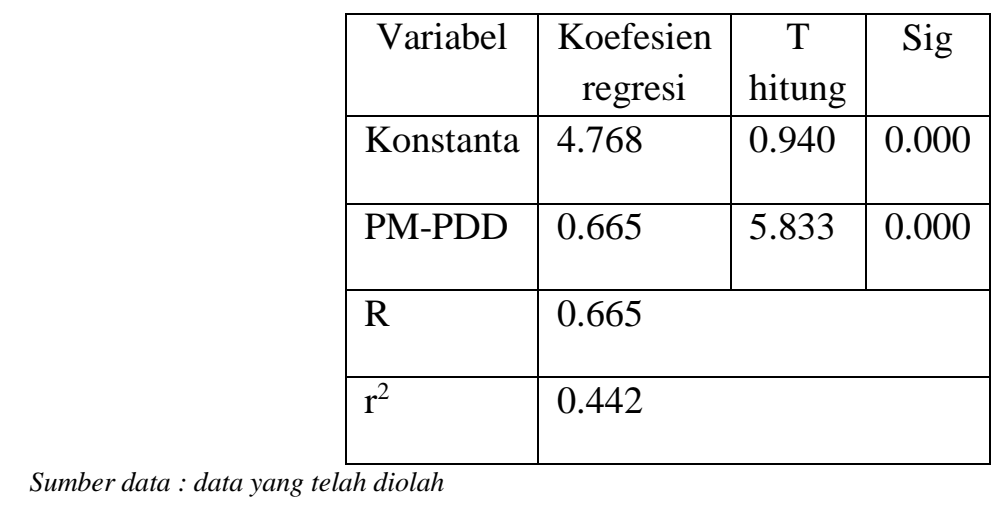

Hasil dari pengolahan data partisipasi masyarakat ialah partisipasi masyarakat berpengaruh positif terhadap pengelolaan dana desa kemudian $\mathrm{r}^{2}$ yang dihasilkan adalah 0.442 berarti sebesar $44,2 \%$ perubahan yang terjadi pada pengelolaan dana desa disebabkan oleh partisipasi masyarakat dengan segnifikansi sebesar 0.000. para aparatur desa bersama-sama dengan masyarakat memutuskan apa yang harus diprioritaskan dalam musyawarah dusun , musyawarah desa hingga musyawarah perencanaan pembangunan desa (musrenbang des). Masyarakat dilibatkan bukan hanya pada saat rapat saja , tapi pada pelaksanaanya masyarakat dilibatkan dengan cara membuat tim untuk proyek pembangunan desa. Antusiasme masyarakat terhadap pengelolaan dana desa bahkan semakin meningkat dari tahun ketahun . Masyarakat bukan hanya ikut berperan didalamnya tapi mereka juga ikut mencari tahu bagaimana distribusi dana desa, apakah sudah turun atau belum. Berdasarkan uraian diatas maka hipotesis dari penelitian ini sejalan atau diterima sesuai dengan penelitian yang dilakukan oleh Julianto (2019:35) yang menyatakan bahwa partisipasi berpengaruh secara positif dan signifikan terhadap keberhasilan pengelolaan dana desa dengan nilai signifikansi sebesar 0.048 .

Berikut ini pengaruh akuntansi dana desa dan partisipasi masyarakat terhadap pengelolaan dana desa : 
Tabel 3. Uji pengaruh akuntansi dana desa dan partisipasi masyarakat terhadap pengelolaan dana desa

\begin{tabular}{|c|c|c|c|c|c|}
\hline \multicolumn{2}{|c|}{ Coefficients $^{\mathbf{a}}$} \\
\hline \multirow{2}{*}{\multicolumn{2}{|c|}{}} & \multicolumn{2}{|c|}{$\begin{array}{c}\text { Unstandardized } \\
\text { Coefficients }\end{array}$} & $\begin{array}{c}\text { Standardized } \\
\text { Coefficients }\end{array}$ & \\
\cline { 2 - 6 } & B & Beta & T & Sig \\
\hline \multirow{2}{*}{1} & (Constant) & 1.139 & & 0.235 & 0.815 \\
\cline { 2 - 6 } & TOTAL_ADD & 0.333 & 0.339 & 2.908 & 0.006 \\
\cline { 2 - 6 } & TOTAL_PM & 0.617 & 0.518 & 4.437 & 0.000 \\
\hline & R & 0.732 & & & \\
\hline & $\mathrm{R}^{2}$ & 0.535 & & & \\
\hline
\end{tabular}

Berdasarkan $\mathrm{r}$ hitung pada variabel $\mathrm{X}^{1}$ sebesar 0.333 maka setiap penambahan nilai 1 pada variabel $\mathrm{X}^{1}$ akan meningkatkan variabel $\mathrm{Y}$ sebesar 0.333 (33.3\%) kemudian sisanya dijelaskan atau dipengaruhi oleh variabel lain sebesar $66.7 \%$. Sedangkan $r$ hitung pada variabel $\mathrm{X}^{2}$ sebesar 0.617 yang berarti setiap penambahan 1 poin pada variabel $\mathrm{X}^{2}$ akan meningkatkan variabel Y sebesar $0.617(61.7 \%)$ dan sisanya dipengaruhi oleh variabel lain sebesar $38.3 \%$.

Sejalan dengan itu, ultafiah (2017:145) yang menyatakan bahwa akuntabilitas dan partisipasi masyarakat berpengaruh secara positif dan signifikan terhadap pengelolaan dana desa dengan Sig. sebesar 0.000 .

Maka dapat disimpulkan bahwa pengaruh akuntansi dana desa dan partisipasi masyarakat terhadap pengelolaan dana desa di sebabkan oleh berbagai faktor selain dari laporan keuangan nya pengelolaan dana desa juga dipengaruhi oleh partisipasi masyarakat baik lewat aspirasi fikirannya maupun sumbangan tenaga dalam pelaksanaan programnya . hal tersebut sejalan dengan teori agensi yang menyatakan bahwa aparatur desa sebagai agen penerima mandat dari pihak masyarakat mempunyai tugas untuk melaksanakan program dana desa secara optimal dan mengkomunikasikan dengan masyarakat lewat melibatkannya dengan rapat yang di adakan oleh dasa.

\section{Kesimpulan}

Berdasarkan hasil penelitian yang telah disampaikan pada bab sebelumnya ,yaitu tentang Pengaruh Akuntansi Dana Desa dan Partisipasi Masyarakat terhadap pengelolaan dana desa di Kabupaten Bandung Barat maka dapat ditarik kesimpulan sebagai berikut:

1. Terdapat pengaruh Akuntansi dana desa terhadap pengelolaan dana desa. Dengan adanya laporan keuangan maka para aparatur desa harus memahami peristiwa akuntansi yang terjadi didalamnya sebagai bentuk tanggung jawab dan pembuktian bahwa aparatur desa akan memberikan yang terbaik bagi pihak prinsipal (masyarakat).

2. Terdapat pengaruh partisipasi masyarakat terhadap pengelolaan dana desa

Dengan adanya musyawarah dusun dan desa maka terjadi komunikasi yang baik dan program-program yang dihasilkan sesuai dengan prioritas desa.

\section{E. Saran}

Berdasarkan hasil kesimpulan diatas , maka dapat dierikan saran mengenai Pengaruh akuntansi dana desa dan partisipasi masyarakat terhadap pengelolaan dana desa di Kabupaten Bandung Barat yaitu:

\section{Saran Teoritis}

Sebaiknya untuk penelitian selanjutnya dianjurkan untuk menambahkan jumlah kabupaten yang diambil untuk memperdalam lagi penelitian.

\section{Saran Praktis}

Sebaiknya aparatur desa lebih terbuka pada masyarakat dengan mengadakan sosialisasi lebih 
lanjut terkait dana desa. Kemudian sebaiknya informasi desa juga dapat diakses oleh pihak eksternal lainnya . Aparatur desa juga sebaiknya mengadakan kerjasama dengan instansi yang terkait agar mendapatkan binaan teknologi maupun yang terkait dengan pencatatan laporan keuangan hingga pelaporan pengelolaan dana desa . Agar mendapatkan pembinaan secara menyeluruh. Pemberdayaan sumber daya manusia juga sebaiknya bekerja sama dengan instansi yang lain agar tidak selalu bergantung pada dana desa

\section{Daftar Pustaka}

[1] Bastian, indra. 2015, Akuntansi untuk Kecamatan dan Desa. Jakarta: Erlangga

[2] Headline : misteri desa siluman salah data atau modu sedot dana desa, Tersedia di: https://www.liputan6.com/news/re d/4108390/headline-misteri-desa siluman-salah-data-atau-modus sedot-dana-desa

[3] Jensen and Meckling. 1976. Theory of the Firm: Managerial Behavior, Agency Costs and Ownership Structure. Journal of Financial Economics . Vol. 3 Iss 4 pp 308

[4] Julianto, dewi, 2019 . Pengaruh partisipasi masyarakat, penggunaan sistem keuangan daerah, kompetensi pendamping desa terhadap keberhasilan pengelolaan dana desa . Bali : Jurnal ilmiah akuntansi Vol 4 No 1

[5] Korupsi Dana Desa Rp 137,9 Juta, Seorang Kades Ditahan,tersedia di: https://regional.kompas.com/read/017/05/23/11545871/korupsi.dana desa.rp.137.9.juta.seorang.kades.diahan

[6]Peraturan Menteri Dalam Negri No.113 pasal 1 ayat 6 Tahun 2014 tentang Pengelolaan Keuangan Desa

[7] Putri, Rahma., Fadilah, Sri dan Nurhayati. 2016. Pengaruh Penerapan Sistem Pengendalian Intern Pemerintah (SPIP) dan Kompetensi Sumber Daya Manusia terhadap Kualitas Pelaporan Keuangan Daerah (Survey pada Pemerintah Daerah di Wilayah Bandung Raya). $\quad$ Prosiding Akuntansi. Vol. 2., No. 2

[8] Ratmono, Dwi \& Solihin, Mahfud.. 2015. Akuntansi Keuangan Daerah Berbasis Akrual .Yogyakarta. UPP STIM YKPN.

[9] Ultafiah weny, 2017. Pengaruh akuntabilitas, transparansi, partisipasi terhadap pengelolaan dana desa untuk mewujudkan Good corporate governance. Palembang: UMP

[10] Undang-Undang No 32 Tahun 2004tentang Desentralisasi

[11] Undang-Undang No.6 Tahun 2014 tentang Desa.

[12] Undang-Undang No.32 Tahun 2004tentang Pemerintahan Daerah.

[13] V Wiratna, Sujarweni 2015. Akuntansi Desa: Panduan Tata Kelola Keuangan Desa. Wonosari: Pustaka Baru Pers

[14] V Wiratna, Sujarweni . 2014 . Akuntansi Dana Desa : Panduan Tata Kelola Keuangan Desa. Wonosari: Pustaka Baru Pers 